\title{
Microencapsulation of indigenous probiotic Lactobacillus plantarum Dad-13 by spray and freeze-drying: strain-dependent effect and its antibacterial property
}

\author{
${ }^{1.2}$ Kamil, R.Z., ${ }^{1}$ Yanti, R., ${ }^{1}$ Murdiati, A., ${ }^{3}$ Juffrie, M. and ${ }^{1,2, * \text { Rahayu, E.S. }}$ \\ ${ }^{1}$ Department of Food and Agricultural Product Technology, Faculty of Agricultural Technology, \\ Universitas Gadjah Mada, Jl. Flora No 1 Bulaksumur, Yogyakarta 55281, Indonesia \\ ${ }^{2}$ Center for Food and Nutrition Studies, Universitas Gadjah Mada, Jl. Teknika Utara Barek, Yogyakarta \\ 55281, Indonesia \\ ${ }^{3}$ Faculty of Medicine, Public Health and Nursing, Universitas Gadjah Mada, Yogyakarta, Indonesia
}

Article history:

Received: 15 June 2020

Received in revised form: 16 July 2020

Accepted: 9 August 2020

Available Online: 26

September 2020

\section{Keywords:}

Microencapsulation,

Spray-drying,

Freeze-drying,

Strain-dependent,

L. plantarum Dad-13,

L. plantarum MUT 7

DOI:

https://doi.org/10.26656/fr.2017.4(6).280

\section{Introduction}

The definition of probiotics, which has been clearly described by FAO/WHO (2002), is a live microorganism that when administered in an adequate amount, could have a beneficial effect on the host. The beneficial effect of probiotic is improving gastrointestinal function, modulation immune response, pathogen inhibitor, reduce irritable bowel syndrome/inflammatory bowel disease's symptoms, and prevention of colon cancer (Parvez et al., 2006; Anal and Singh, 2007; Kechagia et al., 2013). Probiotic has an enormous potential to be extended to another form, and it is not only limited to dairy products. Furthermore, probiotic-supplemented food can be considered as a functional food due to its health benefits (Floch, 2014). Nowadays, people have developed an interest in foods having functional properties.
Most of the probiotic candidates are lactic acid bacteria from Lactobacillus and Bifidobacterium genus (Holzapfel et al., 2001). Also, yeast such as Saccharomyces cerevisiae has also been identified to exhibit probiotic properties (Floch, 2014). A new strain of indigenous probiotic has been successfully isolated from Indonesian traditional fermented food, it is $L$. plantarum Dad-13 which was isolated from Dadih, a spontaneously fermented buffalo milk. Characterization of probiotic properties of $L$. plantarum Dad-13 had been done by Rahayu et al. (2015) which showed that $L$. plantarum Dad-13 has antimicrobial activity and tolerance to the gastrointestinal tract.

Several clinical research of L. plantarum Dad-13 is promising for its development, and one of them is probiotic-supplemented food. According to Pamungkaningtyas et al. (2018), yoghurt fermented by $L$. 
plantarum Dad-13 in combination with indigenous Streptococcus thermophilus Dad-11 has better sensory acceptance compared to the combination of Lactobacillus bulgaricus and S. thermophilus. As the definition of probiotic by $\mathrm{FAO} / \mathrm{WHO}$ that probiotic should be consumed in live cell and adequate amount, maintaining the stability and viability of probiotic cells incorporated in food is very important yet challenging. Factors such as temperature, $\mathrm{pH}$, oxygen availability, water activity, and moisture content are the most crucial factors affecting the stability of probiotic. Meanwhile, according to (Barbosa et al., 2015), probioticsupplemented food should retain the viability of $10^{6}-10^{7}$ $\mathrm{CFU} / \mathrm{g}$ or $/ \mathrm{mL}$ at the end of the expired date. Probiotics supplemented into cornelian cherry juice could not withstand the natural $\mathrm{pH}$ of the juice during seven days of storages (Nematollahi et al., 2016). The sufficient probiotic viability is targeted to survive under the gastrointestinal condition and colonized on the colon. Therefore, the development of new strain probioticsupplemented food is concerned with maintaining the viability during process and storage.

Microencapsulation of probiotic is one of the methods that can be applied to extend the probiotic. It is a technology to protect the unstable compound (gas, liquid or solid) using protective wall material (polysaccharide, lipid, and protein) and control release of its compound to reach the target (Anal and Singh, 2007; Quintanilla-Carvajal et al., 2010; Eckert et al., 2017). The product of microencapsulation is then called as a microcapsule. Spray-drying and freeze-drying are the two most common methods of probiotic microencapsulation (Barbosa et al., 2015; Dianawati et al., 2016; Moayyedi et al., 2018). In addition, a different method may give different characteristics of a microcapsule. However, although the microencapsulation of probiotic has been conducted in several research projects, its effect on probiotic is straindependent (Del Piano et al., 2006; Huang et al., 2017).

Therefore, in this research, microencapsulation of indigenous probiotic strain L. plantarum Dad-13 using spray-drying and freeze-drying method was studied in which $10 \%(\mathrm{w} / \mathrm{v})$ skim milk and $1 \%(\mathrm{w} / \mathrm{v})$ sucrose was used as the wall material. This research aimed as a preliminary study to choose the suitable method for microencapsulation of indigenous probiotic strain for further research. The strain-dependent effect of microencapsulation method was evaluated from injured cells and stability of probiotic after the process, in which L. plantarum Mut-7 was used for comparison.

\section{Materials and methods}

\subsection{Bacterial strains}

To analyze strain-dependent effect, L. plantarum Mut-7, which was isolated from fermented cassava, was used as a comparison. Four pathogenic bacteria were used for antibacterial activity analysis, which was: Listeria monocytogenes ATCC 7644, Staphylococcus aureus ATCC 6538, Escherichia coli IFO 3301 and Salmonella enterica ser. Typhimurium IFO 13245. All the bacterial strains were obtained from the Center for Food and Nutrition Study, Universitas Gadjah Mada. For culture stock, the cell was kept at $-40^{\circ} \mathrm{C}$ within vial containing 1:1 20\% glycerol/10\% skim milk.

\subsection{Growth Condition}

Before the microencapsulation, probiotic strains were inoculated in MRS (de Man, Rogosa and Sharpe) broth. Meanwhile, the pathogenic bacteria were inoculated in nutrient broth. All the bacteria were incubated at $37^{\circ} \mathrm{C}$ for $24 \mathrm{hrs}$ and sub-cultured twice into a new broth medium.

\subsection{Microencapsulation of L. plantarum strain Dad-13 and Mut-7}

Microencapsulation was adapted from (Harmayani et al., 2001) with modification. After the propagation step, the probiotic cell was harvested by centrifuging at $4^{\circ} \mathrm{C}$ $4000 \mathrm{rpm}$ for 15 mins (Thermo scientific). Wall material solution was prepared by diluting $10 \%(\mathrm{w} / \mathrm{v})$ skim milk and $1 \%(\mathrm{w} / \mathrm{v})$ sucrose into aquadest followed by pasteurizing the solution at $100^{\circ} \mathrm{C}$ for 15 mins. The bacterial pellet was then suspended into the solution and homogenized afterwards. Spray-drying was carried out with a lab-scale co-current spray-dryer (LabPlant spraydryer SD-05) with process condition was as followed: inlet-outlet temperature $\left(100-60^{\circ} \mathrm{C}\right)$ and feed velocity $(400-450 \mathrm{~mL} / \mathrm{h})$. For freeze-drying, the bacterial suspension was frozen at $-40^{\circ} \mathrm{C}$ for $24 \mathrm{hrs}$ and then freeze-dried for $72 \mathrm{hrs}$. The freeze-dried microcapsule was then crushed with pestle and mortar. Both spray and freeze-dried microcapsules were seal-packed within an aluminum foil and stored at two temperatures $\left(25^{\circ} \mathrm{C}\right.$ and $4^{\circ} \mathrm{C}$ ) for 8 weeks.

\subsection{Characteristics analysis}

\subsubsection{Yield process}

After each process, microencapsulation yield (\%) was determined with the formulas as follow:

$$
\% \text { Yield }=\frac{M 1}{M 0} \times 100 \%
$$

Where M1 is the weight of microcapsule after the process and M0: the weight of initial total solid in liquid 
feed

\subsubsection{Moisture content and water activity}

Moisture content was measured by gravimetric method while water activity using $\mathrm{a}_{\mathrm{w}}$ meter ( $\mathrm{pa}_{\mathrm{w}} \mathrm{kit}$ ).

\subsubsection{Color measurement}

The color of microcapsule was measured using chromameter (Minolta CR-310) with three parameters ( $\mathrm{L}^{*}, \mathrm{a}^{*}$ and $\mathrm{b}^{*}$ ).

\subsubsection{Dissolution test}

This test is according to (Quek et al., 2007) where 50 $\mathrm{mg}$ of each microcapsule was mixed with $1 \mathrm{~mL}$ of distilled water using a vortex. Dissolution was measured as the time (s) taken to dissolve the powders completely.

\subsubsection{Microstructure analysis}

The analysis of microstructure of probiotic was performed by Scanning Electron Microscopy (SEM JEOL JSM-6510 LA). The samples were mounted on a stub of metal with adhesive, coated with $40-60 \mathrm{~nm}$ of metal such as Gold/Palladium and then observed in the microscope.

\subsubsection{Size particle analysis}

The particle size was measured by a laser particle size analyzer (Malvern Zetasizer Nanoseries Nano ZS ver 7.01). Prior to the analysis, the probiotic microcapsule was dispersed into aquadest $(1: 10 \mathrm{w} / \mathrm{v})$.

\subsection{Survival and stability of probiotic microcapsule during process and storage}

2.5.1 Enumeration of a bacterial cell, survival and sublethal injury analysis

The viable cell was enumerated before and after the drying process and the weekly interval during eight weeks of storage. After rehydration of $1 \mathrm{~g}$ microcapsule into $9 \mathrm{~mL}$ of $0.85 \% \mathrm{NaCl}$ and homogenization for $1 \mathrm{~min}$, at proper dilution, the suspension was pour plated on MRS medium and incubated at $37^{\circ} \mathrm{C}$ for $48 \mathrm{hrs}$. Meanwhile, for sublethal injury analysis, it was pourplated on MRS medium added with $0.15 \%$ bile salt (BS) and incubated at $37^{\circ} \mathrm{C}$ for 5 days. The viable cell was express as $\log \mathrm{CFU} / \mathrm{g}$.

\subsubsection{Inactivation rate during storage}

During eight weeks of storage, the viable cell was analyzed weekly, and the inactivation rate was expressed as logarithmic following the first-order kinetics as described below:

$$
\log \mathrm{Nt}=\log \mathrm{No}+\mathrm{k}_{\mathrm{T}} \mathrm{t}
$$

where No is initial viable cell (CFU/g), Nt is viable cell counts in every week storages (CFU/g), $t$ is a time of storage, and $\mathrm{k}_{\mathrm{T}}$ is the inactivation rate constant at temperature $\mathrm{T}\left(\right.$ week $\left.^{-1}\right)$

\subsection{Antibacterial activity}

Antibacterial activity analysis was conducted according to Papamanoli et al. (2003) with modification. In brief, $1 \mathrm{~mL}$ of pathogen bacteria (viability $10^{6} \mathrm{CFU} /$ $\mathrm{mL}$ ) were pour platted into NA medium and waited until the medium solidified. The solid medium was then plugged for making well (4 wells in each Petri). Cell-free supernatant of a fresh overnight culture of L. plantarum Dad-13 and powder L. plantarum Dad-13 grown in MRS broth was used for antibacterial analysis. Approximately $50 \mu \mathrm{L}$ of supernatant were dropped into the wells. Sterile water and amoxicillin $(10 \mu \mathrm{g} / 100 \mu \mathrm{L})$ were used respectively at the same volume for negative and positive control. Petri was incubated $24 \mathrm{hrs}, 37^{\circ} \mathrm{C}$. Antimicrobial activity was determined by clear zone measurement around the wells (mm).

\subsection{Statistical analysis}

A one-way ANOVA followed by the Duncan Multiple Range Test (DMRT) was performed to evaluating any significant differences in all samples and independent t-test for each treatment. All statistical analysis was performed using IBM SPSS Statistic 24 with confidential ( $p$ value $<0.05$ ).

\section{Results and discussion}

\subsection{Probiotic's microcapsule characteristics}

The yield process shows the efficiency of both microencapsulation methods. Spray and freeze-dry had different yields, which were $45.78 \%$ and $44.88 \%$ for spray-dry of Dad-13 and Mut-7 strains respectively, while $69.80 \%$ and $67.53 \%$ for freeze-drying of Dad-13 and Mut-7 strains respectively. The same result was obtained by Wilkowska et al. (2016), who explained the lower yield in spray-drying process is due to some of the powder stuck on the cyclone or lost blown during the process. The overall characteristic of probiotic's microcapsules can be seen in table 1 . As can be seen, there was no significant difference in dissolution and moisture content from both processes and strains. However, freeze-dried microcapsule had faster dissolution time and higher moisture content. Dissolution time expresses the required time for the microcapsule to well rehydrated in the water. It is an essential aspect for the homogeneity of probiotic supplemented into food. The high moisture content of microcapsule has a tendency to agglomerate and quickly reconstitute in the water (Quek et al., 2007). In addition, freeze-dried 
Table 1. Characteristic of spray and freeze-dried L. plantarum strain Dad-13 and Mut-7

\begin{tabular}{lcccc}
\hline \multirow{2}{*}{ Characteristics } & \multicolumn{2}{c}{ Spray drying } & \multicolumn{2}{c}{ Freeze drying } \\
\cline { 2 - 5 } & Dad-13 & Mut-7 & Dad-13 & Mut-7 \\
\hline dissolution (s) & $14.33 \pm 0.57$ & $13.33 \pm 3.51$ & $12 \pm 3.6$ & $11 \pm 1.0$ \\
moisture content (\%) & $6.28 \pm 0.26$ & $6.47 \pm 0.25$ & $6.19 \pm 0.28$ & $6.28 \pm 0.96$ \\
$\mathrm{a}_{\mathrm{w}}$ & $0.43 \pm 0.01^{\mathrm{b}}$ & $0.47 \pm 0.02^{\mathrm{c}}$ & $0.44 \pm 0.01^{\mathrm{b}}$ & $0.40 \pm 0.02^{\mathrm{a}}$ \\
Color & & & & \\
$\mathrm{L}^{*}$ & $83.26 \pm 0.04^{\mathrm{a}}$ & $83.31 \pm 0.07^{\mathrm{a}}$ & $87.02 \pm 0.01^{\mathrm{b}}$ & $87.12 \pm 0.09^{\mathrm{b}}$ \\
$\mathrm{a}^{*}$ & $5.17 \pm 0.02^{\mathrm{b}}$ & $4.65 \pm 0.19^{\mathrm{a}}$ & $4.69 \pm 0.01^{\mathrm{a}}$ & $4.69 \pm 0.02^{\mathrm{a}}$ \\
$\mathrm{b}^{*}$ & $12.59 \pm 0.07^{\mathrm{b}}$ & $12.68 \pm 0.40^{\mathrm{b}}$ & $9.65 \pm 0.06^{\mathrm{a}}$ & $9.69 \pm 0.04^{\mathrm{a}}$ \\
particle diameter $(\mu \mathrm{m})$ & $0.28 \pm 0.003^{\mathrm{a}}$ & $0.30 \pm 0.001^{\mathrm{b}}$ & $0.47 \pm 0.008^{\mathrm{c}}$ & $0.51 \pm 0.007^{\mathrm{d}}$ \\
\hline
\end{tabular}

Values with different letters within the same column differ significantly $(\mathrm{p}<0.05)$

microcapsule has high rehydration capacity (Barbosa et al., 2015), which due to the porous structure as can be seen in Figure 1.

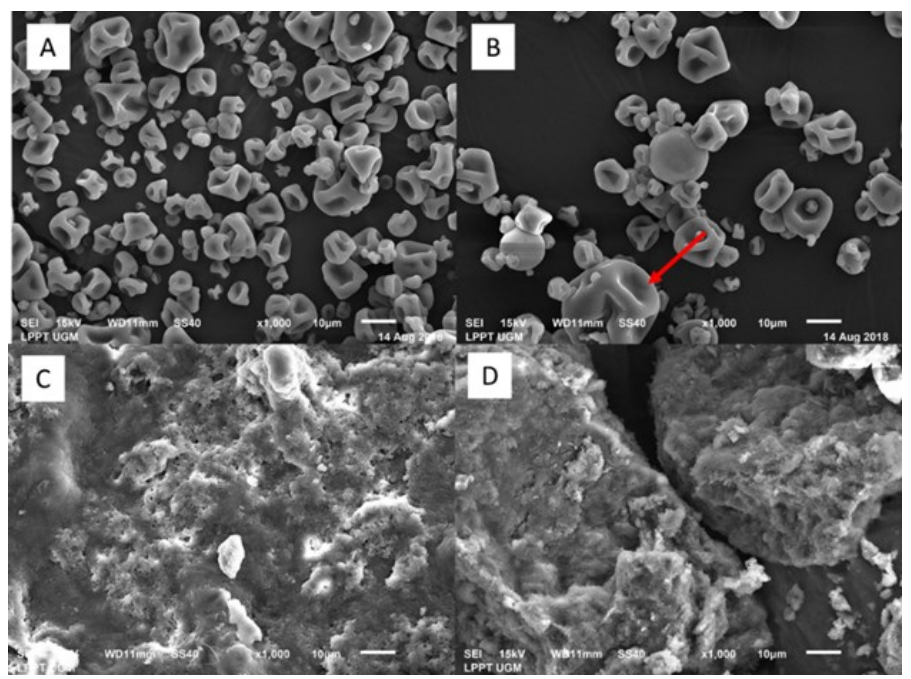

Figure 1. Morphology of spray (A: L. plantarum Dad-13; B: L. plantarum Mut-7) and Freeze (C: L. plantarum Dad-13; D: L. plantarum Mut-7) Dried Probiotic. The arrow showed the wrinkle on the surface of spray-dried microcapsule.

Significant differences were observed in water activity, color and particle diameter. Freeze-dried microcapsule had higher water activity compared to spray-dried microcapsule. Besides that, freeze-dried microcapsule also had a higher lightness and less yellowish intensity. The use of high temperatures in spray-drying leads to a lot of water removal, yet induce browning reactions (Koc et al., 2010). However, according to Kumar and Mishra (2004), to maintain the stability of probiotic's microcapsules, it should have water activity below $0.20-0.25$ and moisture content below $4-5 \%$.

Freeze-dried microcapsule had bigger particle diameter compared to that of the spray-dried microcapsule. Since the feed solution was the same for both methods, the difference in particle size may be affected by the process parameter and post-treatment. The same result is also reported by Moayyedi et al. (2018) and Ying et al. (2010). The smaller size of spray- dried microcapsule due to the feed solution is sprayed through the nozzle. Meanwhile, freeze-dried microcapsule must be manually grinding after the process.

Figure 1 shows the morphology of microcapsule from both methods. Spray-dried-microcapsule had spherical and wrinkle appearance on the surface, while freeze-dried microcapsule had a porous and irregular shape. The wrinkle appearance of spray-dried microcapsule was probably a result of a rapid moisture loss during the process (Wilkowska et al., 2016).

\subsection{Effect of different methods on cell viability}

Several research projects have been reported that skim milk is one of the suitable wall materials for probiotic microencapsulation (Ananta et al., 2005; Liao et al., 2017). Skim milk has the buffering capacity and forms hydrogel on the surface of the probiotic cell, that able to inhibit diffusion of acid when it passes the gastrointestinal tract (Livney, 2010). Therefore, in this research, skim milk was used as a wall material. The effect of spray and freeze-dry on probiotic cell viability is shown in Figure 2.

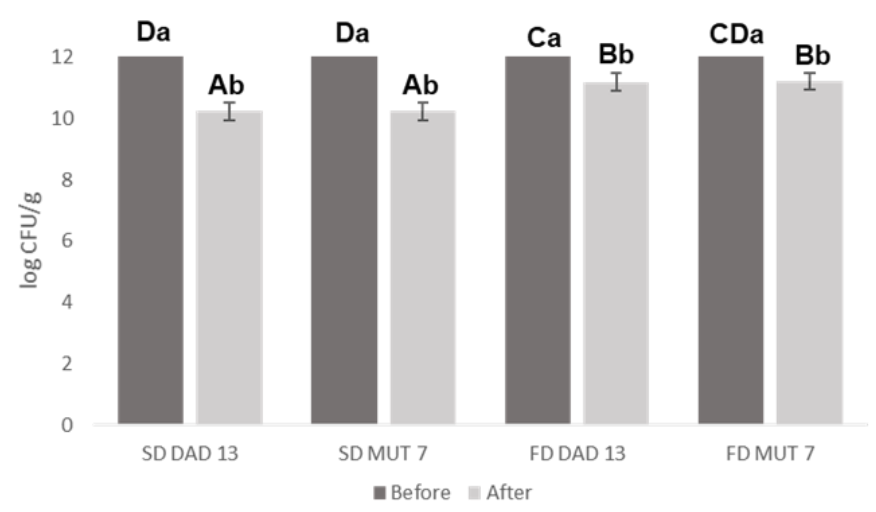

Figure 2. Viable cell of probiotics cell before and after process. Bars with different capital letters above are significantly different $(p<0.05)$ between samples while bars with different lowercase letters are significantly different $(p<0.05)$ between treatments. SD: Spray dry, FD: Freeze dry. 
The use of skim milk as a wall material during spray -drying seemed to be less able to protect a probiotic cell from the high temperature of spray-drying. The spraydrying method resulted in the loss of approximately $2 \log$ cycles of viable cells in both strains. Meanwhile, the loss due to freeze-drying was only $0.9 \mathrm{log}$ cycle in both strains. There was no significant difference in viable cells between strains Dad-13 and Mut-7 in both methods. Stress such as heat, osmotic, oxidative and desiccation may have occurred and caused cells inactivation during the drying process (Huang et al., 2017). The use of high temperature during spray-drying lead to rapid water removal, loss of membrane permeability and protein denaturation (Iaconelli et al., 2015). According to Teixeira et al. (1997), not only heat stress occurred during spray-drying but also osmotic stress and oxidative stress. The freeze-drying method is much mild process compare to spray-drying, and water removal is based on the sublimation process from the ice crystals (Broeckx et al., 2016). However, during slow freezing, coarse ice crystal formed and can be a damage for the cell (Fowler and Toner, 2005). The use of skim milk is preventing cell leakage during slow freezing. Skim milk is a noncolligative cryoprotectant and inhibits the formation of coarse crystal ice, which prevents the cell run into mechanical or osmotic stress (Broeckx et al., 2016).

In order to investigate the injured cell after the drying process, the sublethal injury was performed by cultivated on MRS media with BS addition. According to Espina et al. (2016), in the state of sublethal injury, the bacterial cell is metabolically active but unable to grow in laboratory culture media. As can be seen from Figure 3, there was no significant difference in a viable cell on MRS and MRS+BS from both strains with freeze -drying. Meanwhile, a significant difference was observed in both strains with spray-dry. The grown cell on MRS+BS indicates a healthy cell, in which the difference of viable cell between MRS and MRS+BS is the injured cell. Base on that, spray-dried microcapsules had more injured cell compared to freeze-dried microcapsules. In addition, there was no observed significant difference of injured cell between strains Dad -13 and Mut-7 in both methods. Therefore, the straindependent effect of the drying process did not observe in strain Dad-13 and Mut-7. According to Laconelli et al. (2015), L. plantarum is least affected by stress during spray and freeze-drying without a protective agent.

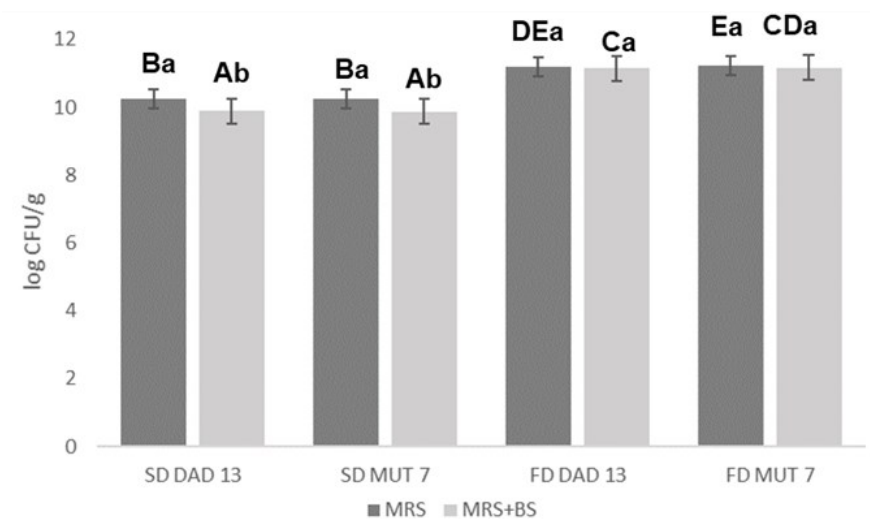

Figure 3. Sublethal Injury of spray and freeze-dried probiotics. Bars with different capital letters above are significantly different $(p<0.05)$ between samples while bars with different lowercase letters are significantly different $(p<0.05)$ between treatments. SD: Spray dry, FD: Freeze dry.

On the contrary, in this research, the spray-drying process caused more injury cells than the freeze-drying process, and it was observed in both strains. Some protein and genes of L. plantarum are known to play a role in heat, oxidative and heat osmotic adaptation mechanisms (Bove et al., 2012; Zotta et al., 2013; Wu et al., 2016). Both strains L. plantarum Dad-13 and Mut-7 are isolated from spontaneously fermented food, which there is no heat treatment (Rahayu et al., 2015). That is maybe because both strains did not have an active adaptation mechanism during high-temperature treatment and have the same viable pattern against the drying process.
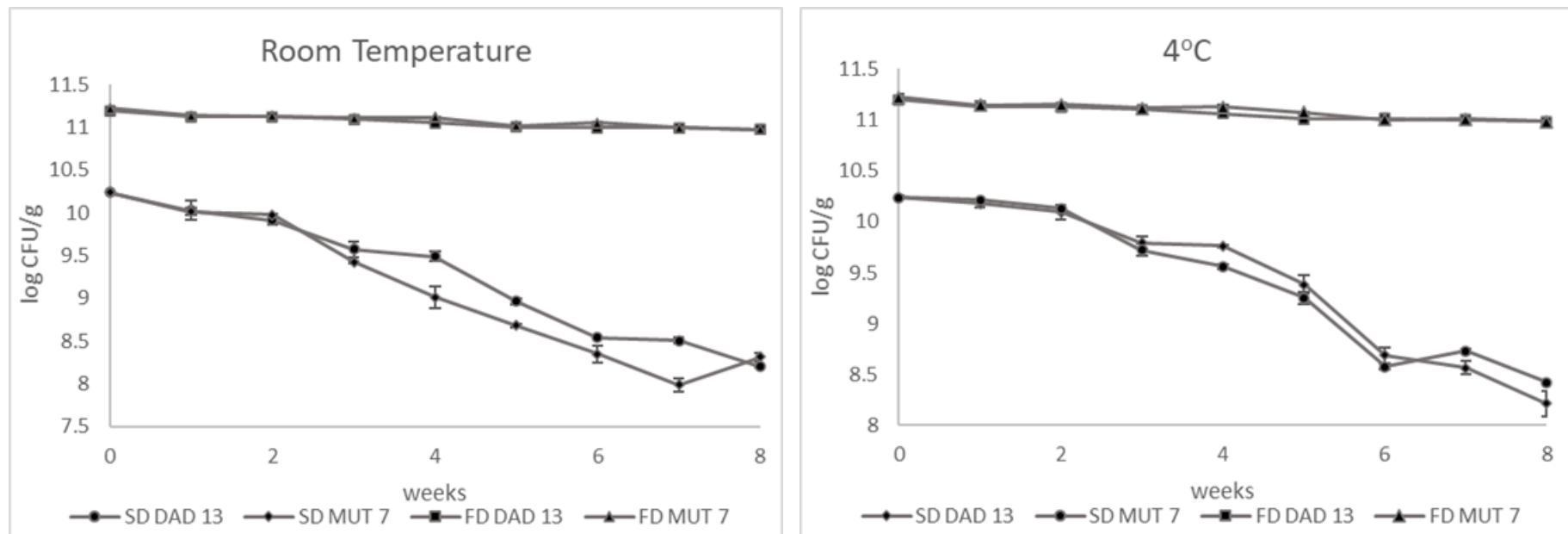

Figure 4. Stability of spray and freeze-dried probiotics during 8 weeks of storage. SD: Spray dry, FD: Freeze dry 


\subsection{Stability of Microcapsule during eight weeks storage}

Stability during eight weeks of storage at two different temperatures of spray and freeze-dried microcapsule can be seen in Figure 4. The viable cell reduction of spray-dried microcapsule during storage was really visible compared to freeze-dried probiotic microcapsule. Furthermore, the effect of storage temperature did not affect the stability of spray and freeze-dried microcapsule. The stability of microcapsules during storage is an important parameter and relates to its shelf-life. Stability at room temperature $\left(25^{\circ} \mathrm{C}\right)$ is desired from probiotic microcapsule due to its low utility cost.

The inactivation rate shows the effect of the environment on the stability of probiotic microcapsule. The less of kT means that the probiotic microcapsule is more stable. All of the microcapsules follow the ordo 1 kinetic reaction, which $\mathrm{kT}$ of freeze-dry probiotic was smaller compare to spray-dried probiotic (Table 2). As those mentioned above, it is clear that freeze-dried probiotic microcapsule was the most stable compared to spray-dried probiotic at the analyzed temperature.

Table 2. Inactivation rate of spray and freeze-dried probiotic during 8 weeks of storage at $25^{\circ} \mathrm{C}$ and $4^{\circ} \mathrm{C}$

\begin{tabular}{cccccc}
\hline \multirow{2}{*}{ Method } & \multirow{2}{*}{ Strain } & \multicolumn{2}{c}{$25^{\circ} \mathrm{C}$} & \multicolumn{2}{c}{$4^{\circ} \mathrm{C}$} \\
\cline { 3 - 6 } & & $\mathrm{k}\left(\right.$ week $\left.^{-1}\right)$ & $\mathrm{R}^{2}$ & $\mathrm{k}\left(\right.$ week $\left.^{-1}\right)$ & $\mathrm{R}^{2}$ \\
\hline Spray & Dad-13 & 0.2682 & 0.9735 & 0.2684 & 0.9303 \\
drying & Mut-7 & 0.2833 & 0.9481 & 0.2544 & 0.9443 \\
Freeze & Dad-13 & 0.027 & 0.9359 & 0.0262 & 0.9408 \\
drying & Mut-7 & 0.0282 & 0.9051 & 0.0284 & 0.9276 \\
\hline
\end{tabular}

High residual moisture content due to inadequate drying process affects the bacteria survival during storage since water is required for physic-chemical reaction (Dianawati et al., 2013). Even though in this research freeze-dried probiotic had slightly higher moisture content compared to spray-dry probiotic, freeze -dried probiotic was more stable during storage. The low survival of spray-dried probiotic may be due to a high number of injured cells during the process. Therefore, the freeze-drying process is more suitable for $L$. plantarum Dad-13 microencapsulation and will be used for further analysis.

\subsection{Antibacterial activity}

Antibacterial activity is one of the probiotic characteristics, which related to the anti-pathogen ability of probiotic. The antibacterial activity comes from bacteriocin, which a protein or polypeptide metabolite produced by the cell (Zacharof and Lovitt, 2012). The result of the antibacterial activity of freeze-dried microcapsule L. plantarum Dad-13 can be seen in Table 3. Although there is an injured cell after the freezedrying process, freeze-dried L. plantarum Dad-13 still showed inhibition against the pathogens, which no significant different with free cell for L. monocytogenes, $E$. coli and $S$. aureus pathogens. However, the inhibition's spectrum was varied in each pathogen. According to Bagad et al. (2017), each antibacterial activity of lactic acid bacteria has its intrinsic biological properties against pathogens. Lacticin, lactocin, pediococin, pisciolin, enterocin, reuterin, plantaricin, eneterolysin and nisin are the common bacteriocin from L. plantarum (Arqués et al., 2015). Therefore, the freezedrying process of $L$. plantarum Dad-13 did not eliminate its probiotic characteristics.

\section{Conclusion}

A significant difference was observed in water activity, color, and particle diameter of spray and freezedried probiotics. Moreover, freeze-dried probiotic had porous morphology, causing it to dissolve easily. Strain dependent effect of spray and freeze-dry probiotic microencapsulation was not observed between $L$. plantarum Dad-13 and Mut-7. Hence, freeze-dried probiotic had higher viable cell and was more stable during storage. Therefore, freeze-dry was considered as a suitable method for $L$. plantarum DAD- 13 'microencapsulations, which freeze dried L. plantarum Dad-13 still had inhibition against pathogens. The use of suitable wall material will be our focus for further research.

\section{Conflict of Interest}

The authors declare that no conflict of interest

Table 3. antibacterial activity of freeze-dried L. plantarum Dad-13

\begin{tabular}{ccccc}
\hline \multicolumn{5}{c}{ Clear Zone $(\mathrm{cm})$} \\
\hline W. monocytogenes & E. coli & S. aureus & S. enterica ser. Typhimurium \\
\hline Amoxicillin & 0 & 0 & 0 & 0 \\
Free cell & $1.88 \pm 0.05^{\mathrm{b}}$ & $1.83 \pm 0.13^{\mathrm{b}}$ & $2.20 \pm 0.22^{\mathrm{b}}$ & $1.55 \pm 0.66^{\mathrm{a}}$ \\
Powder & $1.78 \pm 0.10^{\mathrm{ab}}$ & $1.58 \pm 0.10^{\mathrm{a}}$ & $1.55 \pm 0.10^{\mathrm{ab}}$ & $1.95 \pm 0.06^{\mathrm{c}}$ \\
\hline
\end{tabular}

Values with different letters within the same column differ significantly $(p<0.05)$ 


\section{Acknowledgment}

This research is funded by Ministry of Research, Technology and Higher Education of the Republic of Indonesia (KEMENRISTEK-DIKTI) under the program Pendidikan Magister menuju Doktor untuk Sarjana Unggul (PMDSU) (grant number: 5830/UN1.DITLIT/ DIT-LIT/LT/2018).

\section{References}

Anal, A.K. and Singh, H. (2007). Recent advances in microencapsulation of probiotics for industrial applications and targeted delivery. Trends in Food Science and Technology, 18(5), 240-251. https:// doi.org/10.1016/j.tifs.2007.01.004

Ananta, E., Volkert, M. and Knorr, D. (2005). Cellular injuries and storage stability of spray-dried Lactobacillus rhamnosus GG. International Dairy Journal, 15(4), 399-409. https://doi.org/10.1016/ j.idairyj.2004.08.004

Arqués, J.L., Rodríguez, E., Langa, S., Landete, J.M. and Medina, M. (2015). Antimicrobial activity of lactic acid bacteria in dairy products and gut: Effect on pathogens. BioMed Research International, 2015, 584183. https://doi.org/10.1155/2015/584183

Bagad, M., Pande, R., Dubey, V. and Ghosh, A.R. (2017). Survivability of freeze-dried probiotic Pediococcus pentosaceus strains GS4, GS17 and Lactobacillus gasseri (ATCC 19992) during storage with commonly used pharmaceutical excipients within a period of 120 days. Asian Pacific Journal of Tropical Biomedicine, 7(10), 921-929. https:// doi.org/10.1016/j.apjtb.2017.09.005

Barbosa, J., Borges, S., Amorim, M., Pereira, M.J., Oliveira, A., Pintado, M.E. and Teixeira, P. (2015). Comparison of spray drying, freeze drying and convective hot air drying for the production of a probiotic orange powder. Journal of Functional Foods, 17, 340-351. https://doi.org/10.1016/ j.jff.2015.06.001

Bove, P., Capozzi, V., Garofalo, C., Rieu, A., Spano, G. and Fiocco, D. (2012). Inactivation of the $f t s H$ gene of Lactobacillus plantarum WCFS1: Effects on growth, stress tolerance, cell surface properties and biofilm formation. Microbiological Research, 167 (4), 187-193. https://doi.org/10.1016/ j.micres.2011.07.001

Broeckx, G., Vandenheuvel, D., Claes, I.J.J., Lebeer, S. and Kiekens, F. (2016). Drying techniques of probiotic bacteria as an important step towards the development of novel pharmabiotics. International Journal of Pharmaceutics, 505(1-2), 303-318. https://doi.org/10.1016/j.ijpharm.2016.04.002
Del Piano, M., Morelli, L., Strozzi, G.P., Allesina, S., Barba, M., Deidda, F., Lorenzini, P., Ballare, M., Montino, F., Orsello, M., Satori, M., Garello, E., Carmagnola, S., Pagliarulo, M. and Capurso, L. (2006). Probiotics: from research to consumer. Digestive and Liver Disease, 38(Suppl. 2), S248S255. https://doi.org/10.1016/S1590-8658(07)60004 $-8$

Dianawati, D., Mishra, V. and Shah, N.P. (2013). Survival of Bifidobacterium longum 1941 microencapsulated with proteins and sugars after freezing and freeze drying. Food Research International, 51(2), 503-509. https:// doi.org/10.1016/j.foodres.2013.01.022

Dianawati, D., Mishra, V. and Shah, N.P. (2016). Survival of Microencapsulated Probiotic Bacteria after Processing and during Storage: A Review. Critical Reviews in Food Science and Nutrition, 56 (10), 1685-1716. https:// doi.org/10.1080/10408398.2013.798779

Eckert, C., Serpa, V.G., Felipe dos Santos, A.C., Marinês da Costa, S., Dalpubel, V., Lehn, D.N. and Volken de Souza, C.F. (2017). Microencapsulation of Lactobacillus plantarum ATCC 8014 through spray drying and using dairy whey as wall materials. $L W T$ - Food Science and Technology, 82, 176-183. https://doi.org/10.1016/j.lwt.2017.04.045

Espina, L., García-Gonzalo, D. and Pagán, R. (2016). Detection of thermal sublethal injury in Escherichia coli via the selective medium plating technique: Mechanisms and improvements. Frontiers in Microbiology, 7, 1376-1388. https://doi.org/10.3389/ fmicb.2016.01376

FAO/WHO. (2002). Guidelines for the Evaluation of Probiotics in Food. Retrieved from WHO website: http://www.who.int/foodsafety/fs_management/en/ probiotic_guidelines.pdf

Floch, M.H. (2014). Probiotics and Prebiotics. Gastroenterology and Hepatology, 10(10), 680-681.

Fowler, A. and Toner, M. (2005). Cryo-injury and biopreservation. Annals of the New York Academy of Sciences, 1066(1), 119-135. https://doi.org/10.1196/ annals. 1363.010

Harmayani, E., Ngatirah., Rahayu, E.S. and Utami, T. (2001). Survival and Viability of Lactid Acid Bacteria Probiotic during production of Dried Culture Using Freeze and Spray Drying. Teknologi Dan Industri Pangan, 12(2), 126-132.

Holzapfel, W.H., Haberer, P., Geisen, R., Björkroth, J. and Schillinger, U. (2001). Taxonomy and important features of probiotic microorganisms in food and nutrition. American Journal of Clinical Nutrition, 73 
(Suppl. 2), 365S-373S. https://doi.org/10.1093/ ajen/73.2.365s

Huang, S., Méjean, S., Rabah, H., Dolivet, A., Le Loir, Y., Chen, X.D., Jan, G., Jeanter, R. and Schuck, P. (2017). Double use of concentrated sweet whey for growth and spray drying of probiotics: Towards maximal viability in pilot scale spray dryer. Journal of Food Engineering, 196, 11-17. https:// doi.org/10.1016/j.jfoodeng.2016.10.017

Iaconelli, C., Lemetais, G., Kechaou, N., Chain, F., Bermúdez-humarán, L.G., Langella, P., Gervais, P. and Beney, L. (2015). Drying process strongly affects probiotics viability and functionalities. Journal of Biotechnolgy, 214, 17-26. https:// doi.org/10.1016/j.jbiotec.2015.08.022

Kechagia, M., Basoulis, D., Konstantopoulou, S., Dimitriadi, D., Gyftopoulou, K., Skarmoutsou, N. and Fakiri, E.M. (2013). Health Benefits of Probiotics: A Review. ISRN Nutrition, 2013, 481651. https://doi.org/10.5402/2013/481651

Koc, B., Yilmazer, M.S., Balkir, P. and Ertekin, F.K. (2010). Spray drying of yogurt: Optimization of process conditions for improving viability and other quality attributes. Drying Technology, 28(4), 495507. https://doi.org/10.1080/07373931003613809

Kumar, P. and Mishra, H.N. (2004). Yoghurt powder - A review of process technology, storage and utilization. Food and Bioproducts Processing, 82(2), 133-142. https://doi.org/10.1205/0960308041614918

Liao, L., Wei, X., Gong, X., Li, J. and Huang, T. (2017). Microencapsulation of Lactobacillus casei LK-1 by spray drying related to its stability and in vitro digestion. LWT - Food Science and Technology, 82 (1), 82-89. https://doi.org/10.1016/j.lwt.2017.03.065

Livney, Y.D. (2010). Milk proteins as vehicles for bioactives. Current Opinion in Colloid and Interface Science, 15(1-2), 73-83. https://doi.org/10.1016/ j.cocis.2009.11.002

Moayyedi, M., Eskandari, M.H., Rad, A.H.E., Ziaee, E., Khodaparast, M.H.H. and Golmakani, M.T. (2018). Effect of drying methods (electrospraying, freeze drying and spray drying) on survival and viability of microencapsulated Lactobacillus rhamnosus ATCC 7469. Journal of Functional Foods, 40, 391-399. https://doi.org/10.1016/j.jff.2017.11.016

Nematollahi, A., Sohrabvandi, S., Mortazavian, A.M. and Jazaeri, S. (2016). Viability of probiotic bacteria and some chemical and sensory characteristics in cornelian cherry juice during cold storage. Electronic Journal of Biotechnology, 21, 49-53. https:// doi.org/10.1016/j.ejbt.2016.03.001

Pamungkaningtyas, F.H., Mariyatun, M., Kamil, R.Z.,
Setyawan, R.H., Hasan, P.N., Wiryohanjoyo, D.V., Nurfiani, S., Zulaichah, E., Utami, I.S., Utami, T. and Rahayu, E.S. (2018). Sensory Evaluation of Yogurt-like Set and Yogurt-like Drink Produced by Indigenous Probiotic Strains for Market Test. Indonesian Food and Nutrition Progress, 15(1), 1. https://doi.org/10.22146/ifnp.31010

Papamanoli, E., Tzanetakis, N., Litopoulou-Tzanetaki, E. and Kotzekidou, P. (2003). Characterization of lactic acid bacteria isolated from a Greek dry-fermented sausage in respect of their technological and probiotic properties. Meat Science, 65(2), 859-867. https://doi.org/10.1016/S0309-1740(02)00292-9

Parvez, S., Malik, K.A., Ah Kang, S. and Kim, H.Y. (2006). Probiotics and their fermented food products are beneficial for health. Journal of Applied Microbiology, 100(6), 1171-85. https:// doi.org/10.1111/j.1365-2672.2006.02963.x

Quek, S.Y., Chok, N.K. and Swedlund, P. (2007). The physicochemical properties of spray-dried watermelon powders. Chemical Engineering and Processing: Process Intensification, 46(5), 386-392. https://doi.org/10.1016/j.cep.2006.06.020

Quintanilla-Carvajal, M.X., Camacho-Díaz, B.H., Meraz -Torres, L.S., Chanona-Pérez, J.J., Alamilla-Beltrán, L., Jimenéz-Aparicio, A. and Gutiérrez-López, G.F. (2010). Nanoencapsulation: A new trend in food engineering processing. Food Engineering Reviews, 2, 39-50. https://doi.org/10.1007/s12393-009-9012-6

Rahayu, E.S., Yogeswara, A., Mariyatun, Windiarti, L., Utami, T. and Watanabe, K. (2015). Molecular Characteristics of Indigenous Probiotic Strains from Indonesia. International Journal of Probiotics and Prebiotics, 10(4), 109-116. Retrieved from https:// www.nchpjournals.com/admin/uploads/ article_627.pdf

Teixeira, P., Castro, H., Mohácsi-Farkas, C. and Kirby, R. (1997). Identification of sites of injury in Lactobacillus bulgaricus during heat stress. Journal of Applied Microbiology, 83(2), 219-26. https:// doi.org/10.1046/j.1365-2672.1997.00221.x

Wilkowska, A., Ambroziak, W., Czyzowska, A. and Adamiec, J. (2016). Effect of Microencapsulation by Spray-Drying and Freeze-Drying Technique on the Antioxidant Properties of Blueberry (Vaccinium myrtillus) Juice Polyphenolic Compounds. Polish Journal of Food and Nutrition Sciences, 66(1), 1116. https://doi.org/10.1515/pjfns-2015-0015

Wu, R., Song, X., Liu, Q., Ma, D., Xu, F., Wang, Q., Tang, X. and $\mathrm{Wu}$, J. (2016). Gene expression of Lactobacillus plantarum FS5-5 in response to salt stress. Annals of Microbiology, 66, 1181-1188. https://doi.org/10.1007/s13213-016-1199-1 
Ying, D.Y., Phoon, M.C., Sanguansri, L., Weerakkody,

R., Burgar, I. and Augustin, M.A. (2010).

Microencapsulated Lactobacillus Rhamnosus GG

Powders: Relationship of Powder Physical Properties

to Probiotic Survival During Storage, Journal of Food Science, 75(9), E588-95. https:// doi.org/10.1111/j.1750-3841.2010.01838.x

Zacharof, M.P. and Lovitt, R.W. (2012). Bacteriocins Produced by Lactic Acid Bacteria a Review Article. APCBEE Procedia, 2, 50-56. https:// doi.org/10.1016/j.apcbee.2012.06.010

Zotta, T., Guidone, A., Ianniello, R.G., Parente, E. and Ricciardi, A. (2013). Temperature and respiration affect the growth and stress resistance of Lactobacillus plantarum C17. Journal of Applied Microbiology, 115(3), 848-58. https:// doi.org/10.1111/jam.12285 